\title{
Project brief effects on creative thinking skills among low-ability pre-service physics teachers
}

\author{
Habibi $^{1}$, Mundilarto ${ }^{2}$, Jumadi Jumadi ${ }^{3}$, Syifaul Gummah ${ }^{4}$, Sukainil Ahzan ${ }^{5}$, Dwi Sabda Budi Prasetya ${ }^{6}$ \\ ${ }^{1,2,3}$ Department of Physics Education, Yogyakarta State University, Indonesia \\ ${ }^{4,5,6}$ Physics Education, Universitas Mandalika, Indonesia
}

\section{Article Info \\ Article history: \\ Received Feb 11, 2020 \\ Revised Mar 21, 2020 \\ Accepted May 1, 2020}

\section{Keywords:}

Creative thinking skills

Low ability

Pre-service teachers

Project brief

\begin{abstract}
Creative thinking is high-order thinking that is not easy to stimulate with conventional learning, especially to solve complex physics problems. However, the learning strategy chosen must be in accordance with the teaching materials and students characteristics. Creative thinking is very important especially for low-ability characteristic in solving complicated physics problems; therefore, it needs to be triggered by student-centered learning strategies such as project briefs. This research was to analyze the effect of project brief learning on creative thinking skills (CrTS) of low-ability pre-service physics theacers. Sample was selected using purposive sampling (97 people) in the initial semester pre-service physics teachers which consisted of three classes A (32 people), B (35 people), and C (30 people). Data collection through essay tests on vibration and wave material and adjusted according to the CrTS-Kim indicators. The results show that the project brief has a positive effect on creative thinking skills. The highest effect on the fluency indicator has an average of 15.7 compared to the lecture strategy, as well as the mixture with an average of 9.89 , and the lowest on the originality indicator.
\end{abstract}

This is an open access article under the CC BY-SA license.

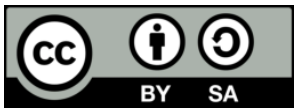

\section{Corresponding Author:}

Habibi,

Departement of Physics Education,

Yogyakarta State University,

J1. Colombo No.1, Karang Malang, Depok, Sleman, D.I.Y. 55281, Indonesia.

Email: habibi.2016@student.uny.ac.id

\section{INTRODUCTION}

Most of the pre-service physics teachers in state universities are more qualified than private universities, especially in Indonesia [1]. It was because the passing grade at state universities was higher and more competitive. In 2019, the Ministry of Higher Education has tightened the admission process at state universities. This causes as many as $23 \%$ of 714,652 students accepted into state universities. Students who do not meet the requirements automatically enrolled in private universities are then categorized as low-ability students. This case is unique because it can affect student interest and learning ability in the lecture process [2], un-confidence [3], low motivation [4], and uninterested in learning [5]. However, in the theory of the education process, it is the educator's challenge to create an interesting, effective and enjoyable learning atmosphere [6]. Therefore, educators must be able to increase learning activities and motivation by using learning strategies that are motivating and learner-centered [7].

One of the student-centered learning strategies is project-based learning (PjBL) [8]. PjBL has two types, namely project brief and full. In lectures, the application of brief projects is considered because it is of short duration. This strategy has had a positive impact on improving critical and creative thinking skills 
(CrTs) [9]. Previous research has presented various positive effects of project-based learning applications. Some of the representatives, Doppelt [10] found that learners have practiced documenting creative processes, teamwork, and reflection. In addition, to promote creativity and problem solving [11], strengthen selfconfidence [12], improve learning achievement [13], and increase learning motivation [14]. Alacapinar [15] states that project learning can influence the originality of learners' thinking. However, originality is an indicator of creative thinking.

Project learning uses problems to trigger learning activities [16]. Boud and Feletti [17] said that problems can construct knowledge, and stimulate learning activities. Quality problems have a positive impact on knowledge and skills in each learning process and produce a variety of works [18]. However, the project brief emphasizes an in-depth process of understanding concepts through quality problems. Emphasis on each process is a strategy to train learners' creative thinking skills.

Creative thinking is a very important skill as a provision for current and future technological progress, even an indicator of the quality of education in countries around the world. In 2018, WEFFI has released a report that the quality of education in Indonesia ranks 43 out of 50 countries in preparing future skills, while Finland is the first. Finland has prioritized creative skills as one of the learning objectives in its curriculum. Creative thinking has been known as a divergent pattern of realistic thinking skills. Creative thinking allows one to connect problems from different perspectives and find unique solutions. Kim [19] has identified this thinking pattern through four indicators of fluency, flexibility, elaboration, and originality. The profile of indicators is as follows: 1) Fluency is the ability to create various unique ideas, 2) Flexibility is an indicator of the ability to express alternative problem solving, 3) Originality; the ability to solve problems with unique concepts, 4). Elaboration is the ability to detail various problems and solutions. Treffinger [20] said that all people have the potential to think creatively; therefore, it is important to choose the right strategy to be able to trigger it.

The application of the project brief is to stimulate the learning motivation of prospective physics teachers, especially those with low abilities. This study shows the effects of conventional strategies on creative thinking to compare their effects to the project brief. The expected impact is students become active and enjoy completing difficult and complex physics concepts. In the future, this strategy can be used as a reference in applying other learning models that are learner-centered.

\section{RESEARCH METHOD}

\subsection{Research design}

In social research, external effects cannot be fully controlled and random group assignments are not possible [21], therefore, this study uses quasi-experiment with pretest-post-test groups' design [22]. Design as follows in Table 1. This study compared three groups of experimental treatments $\left(\mathrm{O}_{1}-\mathrm{O}_{1}^{\prime}\right)$ and controls $\left(\mathrm{O}_{2}-\mathrm{O}_{2}{ }^{\prime}\right)$ and $\left(\mathrm{O}_{3}-\mathrm{O}_{3}{ }^{\prime}\right)$ (Table 1). The experimental group was treated with the PjBL in the category of project brief and with conventional as control, namely lecture, and mixture (lecture and discussion). Treatments are given to examine the effect of creative thinking skills on each indicator simultaneously on basic physics concepts.

Table 1. Design the pretest-posttest groups

\begin{tabular}{ccc}
\hline Pretest Groups & Treatment & Post-test groups \\
\hline$O_{1}$ & Project Brief Learning & $O_{1}{ }^{\prime}$, \\
$O_{2}$ & Lecture & $O_{2}{ }^{\prime}$ \\
$O_{3}$ & Mixture (Lecture and Discussion) & $O_{3}{ }^{\prime}$ \\
\hline Note: $O_{1^{-}} O_{1}^{\prime}$ ': Experimental Groups, $O_{2}-O_{2}{ }^{\prime}$, and $O_{3} O_{3}{ }^{\prime}:$ Control groups
\end{tabular}

\subsection{Sample}

Sample was involved from one of the private universities in West Nusa Tenggara, Indonesia; therefore, their characteristics were categorized as low-ability. Samples were selected using purposive sampling totaling 97 people in the initial semester pre-service physics teachers which consisted of three classes A (32 people), B (35 people), and C (30 people). The purposive sampling technique is used because the sample used has its own characteristics [23]. Class A is assigned as an experimental group because it is treated with a project brief, while classes B and C use conventional learning strategies; therefore, it is assigned as a control class.

Int. J. Eval. \& Res. Educ. Vol. 9, No. 2, June 2020: 415 - 420 


\subsection{Instrument and data analysis}

Data collection through essay tests on vibration and wave material. The score of student answers is adjusted according to the CrTS-Kim indicators. The effects of independent variables are simultaneously analyzed using Multivariate Analysis of Variance (Manova) by SPSS 18. Analysis of Manova has been chosen because the dependent and independent variables are more than two or meet the requirements [24]. Independent variables are the learning strategies of the project brief, lecture, and mixture, while the dependent variables are the four CrTs indicators according to Kim [19], namely: fluency, flexibility, originality, and elaboration. Manova analysis was carried out after fulfilled the prerequisite test, namely, normality and homogeneity.

\section{RESULTS AND DISCUSSION}

The following students' answers description to solve the wave problem seen based on fluency, flexibility, originality, and elaboration indicators. The question: "Ocean waves are formed by tectonic earthquakes where the wavelength and period are 20 meters and 4 seconds. How long does it take (seconds) to get to your house (Please assume the distance of the source to the shoreline is 1 kilometer so you can estimate the distance to your house). Describe the number of waves formed from the source to your home". Student 1 answer for indicators: (a) fluency: data information i.e. wavelength $(\lambda)=20$ meters, period $(T)=4$ seconds to complete travel time (t) to my home which is $(\mathrm{x})=1500$ meters from the shoreline. The next goal is to measure the number of waves ( $\mathrm{n}$ ) from the source to my house, (b) flexibility: if velocity is constant then: $\lambda / \mathrm{T}=\mathrm{x} / \mathrm{t}$, so the propagation time from the wave source to my house is $\mathrm{t}=\mathrm{x}$. $\mathrm{T} / \lambda$ or $\mathrm{t}_{\text {total }}=\mathrm{x}_{\text {total }}$. $\mathrm{T} / \lambda,(c)$ originality: $\mathrm{t}_{\text {total }}=\mathrm{x}_{\text {total }} \mathrm{T} / \lambda=2500 \mathrm{x} 4 / 20=500$ seconds. While the number of waves formed is $\mathrm{n}=$ xtotal $/ \lambda$ or ttotal $/ \mathrm{T}=125$ waves, $(d)$ elaboration: The number of waves $(\mathrm{n})$ can use a comparison of the wavelength $(\mathrm{x})$ to wavelength $(\lambda)$ or the ratio of travel time $(\mathrm{t})$ and period $(\mathrm{T})$. Wavelength is the distance of a hill and valley. This case explores students' creative thinking abilities through variations of answers from an assumption. Analyses of the answers for each score of creative thinking indicators are known through parametric tests.

Normality is needed to test assumptions as well as a prerequisite for parametric tests; therefore, data must be normally distributed. Data that is not normally distributed cannot be analyzed by parametric statistics [25]. Data requirements are normally distributed if sig. $>0.05$, [22]. The results in Table 2 shows that the pretest-posttest data carried out in classes A, B, and C are in sig. $>0.05$, therefore it is concluded that the data. Parametric analysis such as Discriminant and MANOVA requires a homogeneous variancecovariance matrix. The homogeneity requirement is used as a reference to determine the significant effect of the independent variable towards the dependent variable. The homogeneity test results are automatically presented at Manova output. Homogeneous conditions if the output at the Box's M and Levene's test has sig. $>0.05$ [26]. The results show that the Box's M test (Table 3) and Levene's (Table 4) are in the sig. > 0.05 , therefore the data has met the requirements of homogeneity.

Table 2. Normality of CrTS pretest-post-test indicators in each group

\begin{tabular}{ccccccc}
\hline \multirow{2}{*}{ Variants } & \multicolumn{2}{c}{ A } & \multicolumn{2}{c}{ B } & \multicolumn{2}{c}{ C } \\
& Sig & N & Sig & N & Sig. & N \\
\hline Fluency & 0.10 & & 0.26 & & 0.19 & \\
Flexibility & 0.09 & \multirow{2}{*}{32} & 0.15 & 35 & 0.07 & 30 \\
Originality & 0.11 & & 0.09 & & 0.40 & \\
Elaboration & 0.16 & \multicolumn{3}{c}{0.22} & & 0.19 \\
\hline Note: A: Project brief; B: Lecture; C: Mixture (Lecture and Discussion).
\end{tabular}

Table 3. Homogeneity of matrix variants (Box's M)

\begin{tabular}{ccc}
\hline Test & Results & Conclusion \\
\hline Box's M & 20.550 & \\
F & 0.964 & Has been homogeneous \\
Sig. & 0.504 & \\
\hline
\end{tabular}

Table 4. Homogeneity of variants (Levene's test)

\begin{tabular}{ccccc}
\hline Indicators & $\mathrm{F}$ & df1 & df2 & Sig. \\
\hline Fluency & 1.234 & 2 & 94 & 0.296 \\
Flexibility & 1.341 & 2 & 94 & 0.267 \\
Originality & 2.815 & 2 & 94 & 0.065 \\
Elaboration & 1.467 & 2 & 94 & 0.236 \\
\hline
\end{tabular}


The simultaneous influence of the project brief and conventional learning strategies has been shown in the Multivariate test output (Table 5). Learning strategies that have been used have an effect on the independent variable when the sig value. $<0.05,[25]$. The output results show that there are four types of tests suggested namely Pillai's trace, Lamda's wilks, Hottelling's Trace, and Roy's Largest Root which all meet the requirements if sig. $<0.05$ (Table 5), however Wilks' Lamda should be chosen because there are more than two groups in the dependent variable. This indicates that there is a significant difference between the independent variables and the dependent variable simultaneously.

Table 5. Multivariate test

\begin{tabular}{cccccc}
\hline Effects of Learning Strategies & Value & F & df & Error df & Sig. \\
\hline Pillai's Trace & .431 & 6.318 & 8 & 184.000 & .00 \\
Wilks' Lambda & .582 & 7.067 & 8 & 182.000 & .00 \\
Hotelling's Trace & .695 & 7.822 & 8 & 180.000 & .00 \\
Roy's Largest Root & .661 & 15.207 & 4 & 92.000 & .00 \\
\hline
\end{tabular}

Test the effect of the independent variables on the dependent variable (variants) simultaneously shown in the $\mathrm{F}$ test and significant at sig. $<0.05$. The results show that there are differences in the contribution of learning strategies to the CrTS indicator (Table 6). The effect of learning strategies on fluency indicators is $22 \%$ (highest than others). The contribution of learning strategies to indicators of flexibility, originality, and elaboration is $15 \%, 5.6 \%$, and $6.9 \%$. It means that, the effect of learning strategy simultaneously on each CrTS indicator has a difference. The difference in the average score from the confrontation of each learning strategy is presented in Table 7.

Table 6. Test of between subjects' effects

\begin{tabular}{ccccc}
\hline Variants & $\mathrm{F}$ & $\mathrm{N}$ & Sig. & Adjusted R square (\%) \\
\hline Fluency & 15.02 & & 0.000 & 22 \\
Flexibility & 9.655 & & 0.000 & 15 \\
Originality & 3.855 & 97 & 0.025 & 5.6 \\
Elaboration & 4.578 & & 0.013 & 6.9 \\
\hline
\end{tabular}

Table 7. Post-hoc test

\begin{tabular}{|c|c|c|c|c|c|c|}
\hline \multirow{3}{*}{ Variants } & \multicolumn{6}{|c|}{ Multiple Comparisons } \\
\hline & A versus $B$ & & A versus $C$ & & $B$ versus C & \\
\hline & Mean diff. & Sig. & Mean diff. & Sig. & Mean diff. & Sig. \\
\hline Fluency & $15.17 *$ & 0.00 & $9.89 *$ & 0.00 & 5.28 & 0.20 \\
\hline Flexibility & $11.66^{*}$ & 0.00 & 5.11 & 0.20 & 6.55 & 0.05 \\
\hline Originality & $5.00 *$ & 0.01 & 0.43 & 1.00 & 4.57 & 0.08 \\
\hline Elaboration & $11.29 *$ & 0.02 & $0.97 *$ & 0.04 & 1.58 & 1.00 \\
\hline
\end{tabular}

The difference in the average effect of the project brief versus the lecture and the mixture on fluency is 15.17 and 9.89. This indicates that the effect of the project brief is higher than the lecture and mixture specifically for fluency indicators. Likewise, the differences in the effect of the project brief versus lecture on flexibility, originality and elaboration indicators are 11.66, 5.0, and 11.29, while the project brief versus mixture is only significant on fluency (9.89) and elaboration (0.97). These results mean that the effect of project briefs has a more positive impact on the ability to produce various ideas (fluency) in solving physics problems. However, the project brief also contributes to improving flexibility, originality and elaboration abilities. All these indicators are students' creative thinking skills. According to Gunawan [27] that project learning strategy can improve students' creative thinking skills. Project learning also helps in equipping students to explore innovative capabilities needed in the future [28]. In essence, creative individuals will maintain the originality of the ideas produced [29].

In cognitive psychology, learners in higher education include the adult category or at the post-formal reasoning stage [30]. This is characterized by dialectical thinking. Dialectical abilities include understanding, analyzing and finding solutions based on ideas, theories, opinions, and contradictory thoughts that are capable of being synthesized into new and creative thoughts [25]. The level ofcognitive maturity depends on how to process information, improve memory and memory capacity, and organize knowledge to 
solve various problems [26]. These skills are very important specially to support each learning process. Therefore, choosing a unique learning strategy as PBL $[31,32]$ is very important in facilitating creative thinking skills such as learning project briefs. Finally, choosing the right strategy is required to motivate low-ability students.

\section{CONCLUSION}

The selection of appropriate learning strategies contributes positively to the creative thinking skills of low-ability physics teacher candidates. Project briefs are learned-centered proven to be better in improving students' creative thinking abilities than conventional learning. The project brief gives a pleasant learning atmosphere so that students become active in completing complex physics concepts. In the future, this study is expected to be a reference for choosing active learning strategies especially for physics students.

\section{ACKNOWLEDGEMENTS}

This research was supported by the Ministry of Finance and Research and Technology of Higher Education through the BUDI DN scholarship program.

\section{REFERENCES}

[1] Welch, A. R., "Blurred vision?: Public and private higher education in Indonesia," Higher Education, vol. 54, no. 5, pp. 665-687, 2007.

[2] Haskins, R., Walden, T., and Ramey, C. T. "Teacher and student behavior in high-and low-ability groups," Journal of Educational Psychology, vol. 75, no. 6, p. 865, 1983.

[3] Wartono, W., Suyudi, A., and Batlolona, J. R., "Students' problem-solving skills of physics on the gas kinetic theory material," Journal of Education and Learning, vol. 12, nol. 2, pp. 319-324, 2018.

[4] Saleh, M., Lazonder, A. W., and De Jong, T., "Effects of within-class ability grouping on social interaction, achievement, and motivation," Instructional Science, vol. 33, no. 2, pp. 105-119, 2005.

[5] Jang, H., "Supporting students' motivation, engagement, and learning during an uninteresting activity," Journal of Educational Psychology, vol. 100, vol. 4, p. 798, 2008.

[6] Bruner, J. S., The process of education. Harvard University Press, 2009.

[7] Nidzam, C. A. C., and Shaharim Saidatul, A. M. F. N. L., "Teacher-student interactions, learning commitment, learning environment and their relationship with student learning comfort," Journal of Turkish Science Education, vol. 14, no. 1, pp. 57-72, 2017.

[8] Dewi, C. A., and Mashami, R. A., "The Effect of Chemo-Entrepreneurship Oriented Inquiry Module on Improving Students' Creative Thinking Ability," Journal of Turkish Science Education, vol. 11, no. 1, pp. 3-23, 2019.

[9] Talat, A., and Chaudhry, H. F., "The effect of PBL and 21st century skills on students' creativity and competitiveness in private schools," The Lahore Journal of Business, vol. 2, no. 2, pp.89-114, 2014.

[10] Doppelt, Y., "Assessing creative thinking in design-based learning," International Journal of Technology and Design Education, vol. 19, no. 1, pp. 55-65, 2009.

[11] Bell, S., "Project-based learning for the 21st century: Skills for the future," The Clearing House, vol. 83, no. 2, pp. 39-43, 2010.

[12] Zhou, C., "Integrating creativity training into problem and project-based learning curriculum in engineering education," European Journal of Engineering Education, vol. 37, no. 5, pp. 488-499, 2012

[13] Arantes do Amaral, J. A., dos Santos, L., and Rodrigues, R. J., "Combining Project-Based Learning and Community-Based Research in a Research Methodology Course: The Lessons Learned," International Journal of Instruction, vol. 11, no.1, pp. 47-60, 2018.

[14] Baran, M., Maskan, A., and Yasar, S., "Learning Physics through Project-Based Learning Game Techniques," International Journal of Instruction, vol. 11, no. 2, pp. 221-234, 2018

[15] Alacapinar, F., "Effectiveness of project-based learning," Eurasian Journal of Educational Research (EJER), no. 33, pp. 17-34, 2008 .

[16] Fried-Booth, D. L., Project work. Oxford University Press, 2002.

[17] Boud, D. and Feletti, G., The challenge of problem-based learning. Routledge, 2013.

[18] Buck institute of Education, "What is Project-Based Learning?" 2018. [Online]. Available: https://www.pblworks.org/what-is-pbl

[19] Kim, K. H., "The creativity crisis: The decrease in creative thinking scores on the Torrance Tests of Creative Thinking," Creativity Research Journal, vol. 23, no. 4, pp. 285-295, 2011.

[20] Treffinger, D. J., Isaksen, S. G., and Stead-Dorval, K. B., Creative problem solving: An introduction. Prufrock Press Inc, 2005.

[21] Campbell, D. T. and Stanley, J. C., Experimental and quasi-experimental designs for research. Ravenio Books, 2015.

[22] Sugiyono, Educational Research Methods: Quantitative, qualitative, and $R \& D$ approaches (in Bahasa). Alfabeta: Bandung, Indonesia, 2013 
[23] Ghozali Imam, Multivariate Analysis Application with the IBM SPSS 23 Program (in Bahasa)," UNDIP, Semarang, Indonesia, 2016.

[24] Chou, Y. M., Polansky, A. M., and Mason, R. L., "Transforming non-normal data to normality in statistical process control, "Journal of Quality Technology, vol. 30, no. 2, pp. 133-141, 1998.

[25] Rencher, A. C., "A review of "Methods of Multivariate Analysis," 2005.

[26] Geisser, S. and Greenhouse, S. W., "An extension of box's results on the use of the F distribution in multivariate analysis," The Annals of Mathematical Statistics, vol. 29, no. 3, pp. 885-891, 1958.

[27] Gunawan, G., Sahidu, H., Harjono, A., and Suranti, N. M. Y., "The effect of project-based learning with virtual media assistance on student's creativity in physics," Cakrawala Pendidikan, no. 2, 2017.

[28] Montag-Smit, T. and Maertz Jr, C. P., "Searching outside the box in creative problem solving: The role of creative thinking skills and domain knowledge," Journal of Business Research, vol. 81, pp. 1-10, 2017.

[29] Tyagi, V., Hanoch, Y., Hall, S. D., Runco, M., and Denham, S. L., "The risky side of creativity: Domain specific risk taking in creative individuals," Frontiers in psychology, vol. 8, p. 145, 2017.

[30] Runco, M. A., and Chand, I., "Cognition and creativity," Educational psychology review, vol. 7, no. 3, pp. 243-267, 1995.

[31] Batlolona, J. R., Diantoro, M., and Latifah, E., "Creative Thinking Skills Students in Physics on Solid Material Elasticity," Journal of Turkish Science Education, vol. 16, no. 1, pp. 48-61, 2019.

[32] Wartono, W., Diantoro, M., and Bartlolona, J. R., "Influence of problem-based learning model on student creative thinking on elasticity topics a material," Jurnal Pendidikan Fisika Indonesia, vol. 14, no. 1, pp. 32-39, 2018. 